Yoshichiro UMEYA: Fertilizing activity of the sperm entered the matured egg of the silkworm under the low temperatures, with special reference to the heterosis theory. Jap. Jour. Genet. 30 (1955) : 133-138.

\title{
カイコの成熟卵內における精子の低温に対する 受精能力，特にへテロシスについての一考察*
}

\section{梅 谷 與 七 郎 ${ }^{* *}$ \\ 農林省掻系試験場}

昭和 30 年 3 月 1 日受領

\author{
UDC 595. $787: 591.463 .1:$ \\ 591. $3: 575.125: 591$. \\ 465. 1
}

\section{Résumé}

In the egg of the silkworm fertilization under the room temperature generally takes place within approximately 2 hours after insemination. Present experiments are concerned with the tolerance of the fertilizing activity of the sperm within the egg to low temperatures applied at different times prior to the establishment of fertilization.

It was learned that the fertilizing activity of the sperm within the egg was wholly impaired by refrigeration at $2.5^{\circ} \mathrm{C}$. for over 5 days, but normal fertilization took place under the temperature of $5^{\circ} \mathrm{C}$. Accordingly, it appears likely that a critical point might exist within the range between $2.5^{\circ} \mathrm{C}$. and $5^{\circ} \mathrm{C}$. with respect to the temperature effect upon fertilization. It was of most interest to see, as the result of the cooling experiment on the eggs inseminated by the same strain and those laid after mating between different strains, that the fertilizing activity of the sperm in the latter eggs was less affected by low temperature.

Such observations as well as Umeya's experiments that reported in 1930 may throw light for the analysis of the "heterosis theory" which concerns the problem why the vigor of the silkworm is intensified by hybridization. A work is now under the way in connection with the significance of the present finding.

\section{緒言}

1950 年茨城県から採集した天奄藏(俗にノッコという) 約 1000 粒の発蛾は長野県有明村のものと 同様に， 7 月下旬から 8 月上旬頃と期待していたが，ずつとおくれて 10 月下旬頃となり，しかも非 常に不受精卵が多かつたように思われた。ところが松本県亘の西村国男氏がこの不受精と思われた越

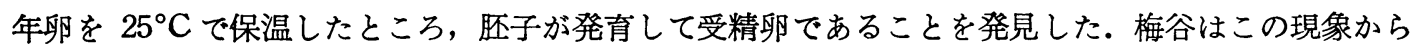
受精していても環境の低温のため受精核の分裂が抑制されていたのでないかとの暗示をうけ，叠卵を 材料にして成熟卵内に侵入した精子が低温下で，どの程度の受精への抑制をうけるかどうかを検討し て見な。そもそもカイコの成熟卵内に入つた精子は卵子が極体を放出して間もなく受精（核の合一） が行なわれるのは $23^{\circ} \sim 25^{\circ} \mathrm{C}$ の室温で約 2 時間を要するとされている. それで精子が成熟卵内に侵 入して未だ受精が起らない期間（ 2 時間以内）にその卵子を冷蔵してのち出庫し, $25^{\circ} \mathrm{C} に$ に保温し,

\footnotetext{
* 本研究は 1951 年第 22 回動物学広島大会の席上で予報す.

** National Sericultural Experiment Station, Tokyo.
} 
その受精による着色化（卵が受精すると黄白卵が着色する）を観察した。ところが面白いことには受 精現象が起る温度に $2.5^{\circ} \mathrm{C}$ と $5^{\circ} \mathrm{C}$ の間に一線を画すべき臨界点があることが明らかとなつた。そ して $2.5^{\circ} \mathrm{C}$ に数日冷蔵すると, 精子の受精力が消失することを見出した。そこでこの事実に立脚し て成熟卵の $2.5^{\circ} \mathrm{C}$ への冷蔵による, 同品種間あるいは異なる品種間における交配による精子の受精 能力を比較検討して，雑種のへテロシス現象に言及することにしたいと思う。

因に本研究に助力をうけた浅野清志, 戸谷和夫両氏に謝意を表する.

\section{実験方法とその材料}

午前中に発蛾した雌雄を室温で約 3 時間交尾せしめてのち産卵せしめた。一般に長時間交尾せしめ て割愛すると母蛾は直ぐに産卵するので, 産卵後 10 分を経過する毎に産卵台紙を集め, これを産卵 時間の基準として, 10 分， 30 分， 1 時間， 2 時間区を設け， $2.5^{\circ} \mathrm{C}$ と $5^{\circ} \mathrm{C}$ とに 1 日より 60 日間 冷蔵してのち，それぞれ $25^{\circ} \mathrm{C} に$ 催青して受精率を調查した。周知の通り受精の有無は着色卯によつ て一目でわかるので, その受精卵数の歩合によつて受精能力を比較検討した。

供試材料は最初晚秋亘の支 $108 \times$ 日115 の雑種を用い, その後は, 支 110 , 日特, 日 111 , などの 固定種を用いた。そしてこれらの材料で, 同品種間あるいは異品種間の交配を行ない, 精子の卵子へ の受精歩合を調べた。なお最後に支 $122 \times$ 日115 の雑種を用いて体内の精子や卵子の冷蔵に対する受 精の抵抗力を検討した。

\section{権 察 結 果}

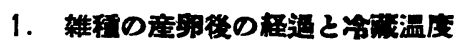

まず材料として雑種（支 $108 \times$ 日 115）を用い，産卵後に一定期間（10 分間， 1 時間， 2 時間） を経過するごとにそれぞれ， $2.5^{\circ} \mathrm{C} と 5^{\circ} \mathrm{C} に 1$ 日から 60 日間冷蔵して後, 催青室 $\left(25^{\circ} \mathrm{C}\right)$ に移 し, 受精の能力（着色卵の歩合）を調査した.

第 1 衰 雑種（支 $108 \times$ 日 115）の産卵後の経過と冷藏における受精歩合

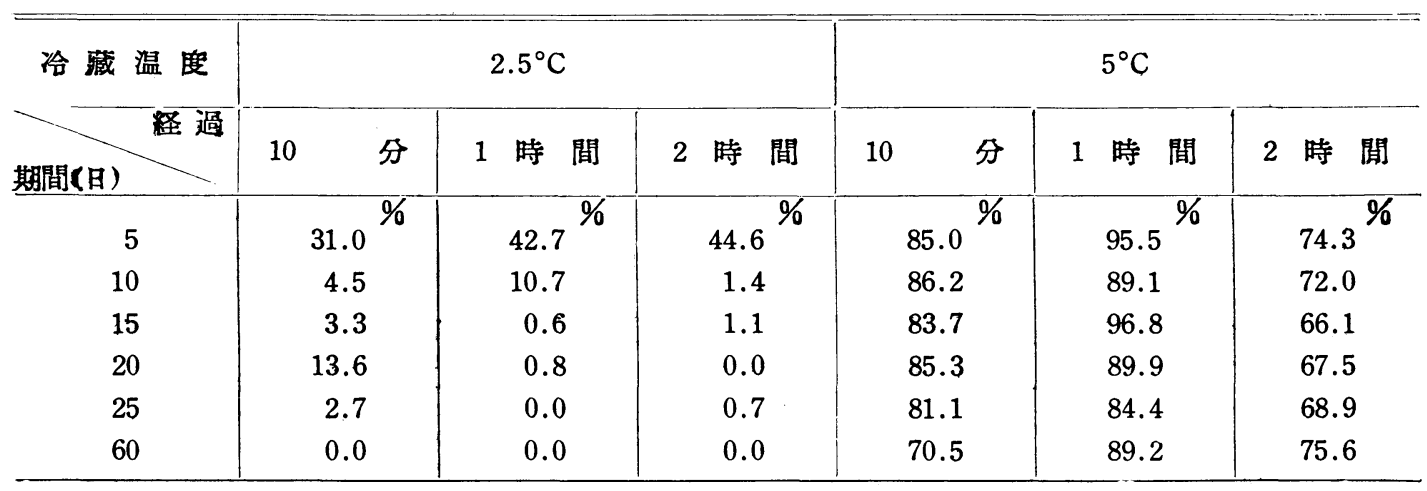

対照区 (無処理) $98.3 \%$

第 1 表に示してあるように, 産卵後の経過即ち 10 分, 1 時間, 2 時間, の各区の間には受精歩合 に大差はないが, 冷蔵温度の $2.5^{\circ} \mathrm{C}$ と $5^{\circ} \mathrm{C}$ の間には 1 線を画すべき臨界点があることがわかつた。 そして $2.5^{\circ} \mathrm{C} に 5$ 日以上冷藏すると, 精子の受精事は著しく低下してくる.これに反して $5^{\circ} \mathrm{C} の$ 冷 蔵に対しては相当な抵抗力があり，命截期間が 60 日の長期におよんでもなお 70\% 以上の受精歩合 を示している.

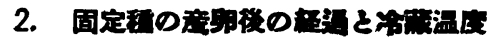


次に材料として用いた支 110 は今日では純系に近い支支 2 化の交雑より分離固定させた品種であ り，また日特種は日支交雑より分離した固定品種である。この 2 品種を材料にして，第 1 表の場合と 同じ方法で冷蔵による受精歩合を調查した。この場合の冷蔵期間は 1 日より 20 日におよんでいる.

第 2 表 固定種支 110 と日特に扣ける受精歩合（\%)

\begin{tabular}{|c|c|c|c|c|c|}
\hline 種 & 名 & \multicolumn{2}{|c|}{ 芰 110} & \multicolumn{2}{|c|}{ 日 特 } \\
\hline \multicolumn{2}{|l|}{ 冷藏日数 } & $2.5^{\circ} \mathrm{C}$ & $5^{\circ} \mathrm{C}$ & $2.5^{\circ} \mathrm{C}$ & $5^{\circ} \mathrm{C}$ \\
\hline \multicolumn{2}{|r|}{1} & $34.6^{\%}$ & $60.3^{\%}$ & $91.5^{\%}$ & $96.9^{9}$ \\
\hline \multicolumn{2}{|r|}{3} & 3.8 & 59.4 & 53.3 & 87.0 \\
\hline \multicolumn{2}{|r|}{4} & 7.3 & 42.9 & 52.6 & 88.4 \\
\hline \multicolumn{2}{|r|}{5} & 14.0 & 37.6 & 45.5 & 66.2 \\
\hline \multicolumn{2}{|r|}{7} & 11.0 & 26.0 & 32.4 & 60.2 \\
\hline \multicolumn{2}{|c|}{10} & 1.8 & 9.4 & 12.7 & 42.6 \\
\hline \multicolumn{2}{|c|}{15} & 0.0 & 0.6 & 5.7 & 30.4 \\
\hline \multicolumn{2}{|c|}{20} & 0.0 & 0.0 & 3.2 & 3.6 \\
\hline 対 & 照 & \multicolumn{2}{|c|}{ (無処理) $97.7 \%$} & \multicolumn{2}{|c|}{ （無処理） $96.7 \%$} \\
\hline
\end{tabular}

上に掲げた第 2 表に示すようにこの場合もまた冷蔵温度 $2.5^{\circ} \mathrm{C}$ と $5^{\circ} \mathrm{C}$ との間に受精力の臨界 点があり, 支 110 では $2.5^{\circ} \mathrm{C}$ の冷蔵が 3 日以上におよぶと受精率が $3.8 \%$ に低下してくるが, 冷蔵 が 5 日より 7 日になると, かえつて 11 14\% の受精歩合を示して, や>増加している（これは一種 の慣れ現象？）しかし 10 日以上の冷蔵では $1 \%$ 前後となつて，受精力がほとんど失われてくる．と ころが $5^{\circ} \mathrm{C}$ では 10 日間冷蔵してもなお $9.4 \%$ の受精率を示している．しかしそれ以上の冷蔵では 受精がほとんど起らない（ $\left(5^{\circ} \mathrm{C} へ\right.$ へ 15 日間冷蔵では $\left.0.6 \%\right)$, 他方において日特の日支固定種では $2.5^{\circ} \mathrm{C}$ に 10 日間冷蔵すると受精率が $12.7 \%$ に低下してくる，とはいえ支 110 のそれと比較するとや >高いし, 冷蔵温度が $5^{\circ} \mathrm{C}$ にると 10 日でもまだ $42.6 \%$ 示していて, $2.5^{\circ} \mathrm{C}$ と $5^{\circ} \mathrm{C}$ の冷蔵に はやはり受精力に判然たる臨界点が認められる. しかし全般的に見て, 純系に近い支 110 の品種に比 して日支交雑種の固定種である日特の受精率が高い傾向があることは注目される.

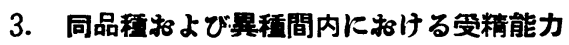

材料として支 110 と日111 を用い，それらの相互間の交配によつて，同品種間および異なる品種 間における受精の状況を観察した結果は次の第 3 表に示す通りである.

因に第 3 表の雑種 $\times$ 支 110 の雑種とは梅谷が保有する死卵系の雑種である.

第 3 銥＼cjkstart冷藏に打ける固定種と雑種の受精歩合

\begin{tabular}{|c|c|c|c|c|c|}
\hline 固定種と雑種 & 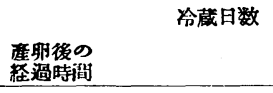 & 3 日 間 & 5 日 間 & 10 日 & 日 間 \\
\hline 支110( \& ) ×支110( & $\begin{array}{l}10 \text { 分 } \\
30 \text { 窎 } \\
1 \text { 時間 }\end{array}$ & $\begin{array}{l}30.0 \\
12.9 \\
22.3\end{array}$ & $\begin{array}{r}7.8 \\
11.9 \\
3.5\end{array}$ & & $\begin{array}{l}1.5 \\
0.0 \\
1.8\end{array}$ \\
\hline 日 $111($ o $) \times$ 支 $110(\delta)$ & $\begin{array}{l}10 \text { 分 } \\
30 \text { 分 } \\
1 \text { 時間 }\end{array}$ & $\overline{\overline{57.0}}$ & $\begin{array}{r}0.0 \\
5.7 \\
33.4\end{array}$ & & $\begin{array}{l}0.9 \\
0.7 \\
0.9\end{array}$ \\
\hline 雑種 (ㅇ）×支110（今） & $\begin{array}{l}10 \text { 分 } \\
30 \text { 分 } \\
1 \text { 時間 }\end{array}$ & $\begin{array}{l}48.6 \\
68.2 \\
35.3\end{array}$ & $\begin{array}{l}49.5 \\
56.1 \\
56.3\end{array}$ & & $\begin{array}{l}3.9 \\
7.1 \\
2.3\end{array}$ \\
\hline
\end{tabular}


第 3表に示すように，同じ品種の卵子に入つた場合である支 110 (ㅇ)×支 110 (今) の受精歩合に 比べて，異なる卵子日 111 に大つた支 110 の精子の受精歩合の方が大きい様相を呈している.（産卵

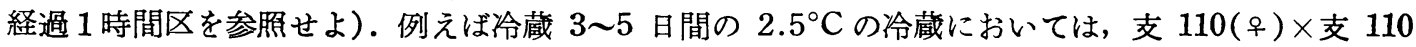
（今）の受精歩合よりも日 111 (早)×支 110 (今) の方が受精率は高い.しかし冷蔵が 10 日におよぶ と, この低温冷蔵が禍して，支 $110 \times$ 支 110 と日 $111 \times$ 支 110 の両者とも受精歩合は $1 \%$ 前後を示 して大差が認められない。しかし前表最後の欄に示す雑種の形, 即ち卵細胞が雑種の形となつている ものの成熟卵内の支 110 の精子の受精歩合（5 日間冷蔵区参照）は約 $50 \%$ 以上を示し，他の同品種 や異品種のものに比して受精率が高いことを示す.そして冷蔵期間が 10 日におよんでもなお 4 〜 \%を示している.この点は興味あることで, 卵子が異なつている場合, とくにこれが雑種の形となつ ているものの卵細胞の中に入つている精子はさらに受精能力が強いことを示す点は興味潹く感ずる.

\section{4. 低温に対する卵子の受精能力}

さて今まで成熟卵内に入つた精子の低温に対する受精力について観察してきたが, 卵細胞それ自身 の低温における精子を受け入れる立場について検討して見よう。しかしわれらの体験から卵子は冷蔵 に対する抵抗力が強く，受精率が相当高いものであることを知つてたが，ここであらためて卵子を冷 蔵した場合における受精能力を検討した。それでまず母蛾を $2.5^{\circ} \mathrm{C} に 5 〜 10$ 日間冷蔵してのち取り 出し, これに健康雄蛾を交配し, 精子の卵子への受精率を支 $122 \times$ 日115 の雑種を材料にして観察し た。その結果は次表に示す通りである.

第 4 表 卵子の低温住対する受精能力

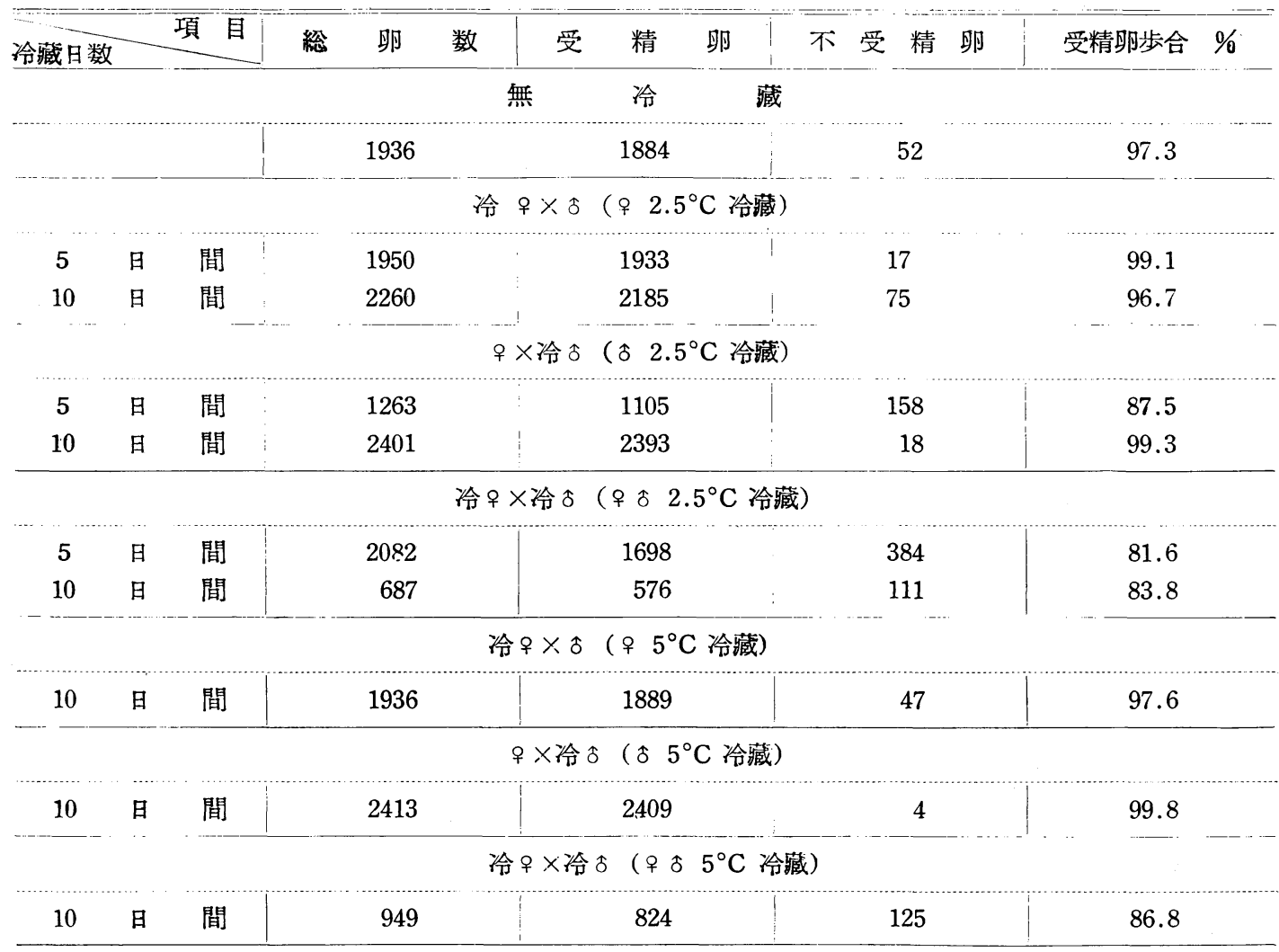

第 4 表に示してあるように，雌蛾や雄蛾を $2.5^{\circ} \mathrm{C} に 5 \sim 10$ 日間冷载して後に，相互に交配して，

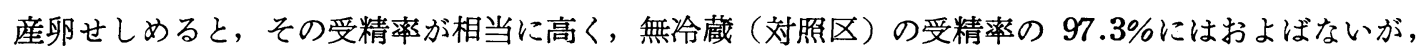


いずれも $90 \%$ 以上の受精率を示し, 卵子の $2.5^{\circ} \mathrm{C}$ 冷蔵による影響はほとんど認められなかつた。 ただしここで考えねばならないことは，卵子は母体の卵管内にあり，精子もまた体内の貯精辢内にあ るので, それらが単独に冷蔵されたものではない。またさきの成熟卵内の精子も精子そのものの冷蔵 でないから，自ら事情が異つている．しかし卵子をとりだして単独に泠蔵して試験すること法不可能 である．上記の観察から大体の傾向として体内にある卵管内の卵子や貯精霬内の精子は低温に対する 抵抗力は単独に冷蔵されたものに比して相当に强いものであることが推定される.

かく卵子は精子と異つて， $2.5^{\circ} \mathrm{C}$ における受精力の臨界点は見出しえなかつたが，卵子は $2.5^{\circ} \mathrm{C}$ に長期冷蔵しても，精子が健在である限り交配による受精能力がかなり高いことがわかる. 故に卵子 に入つた精子（あるいは精核）の冷蔵による受精力については, 卵子の短期間の冷蔵による影響はあ まり梁く考えなくてもよい，それでこの場合は主として精子の $2.5^{\circ} \mathrm{C}$ における冷蔵に対する受精の 影響のみについて検討して差支えないものと思われる。

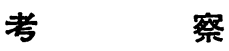

前に述べたように卵子の受精に対する冷蔵抵抗力は精子と異つて, $2.5^{\circ} \mathrm{C} に$ 受精力の臨界点が認め られなかつたが，体内（卵管）の卵子の冷蔵に対する抵抗力は相当に強いものであり，精子が健在で ある限り受精するもののようである。これに反し卵内に入つた精子は， $2.5^{\circ} \mathrm{C}$ 冷蔵によつて受精が

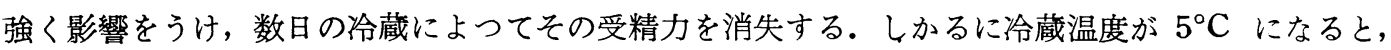
受精が普通に行なわれる. それでも純系に近い固定品種の精子の冷蔵抵抗力が弱く, 冷蔵温度が $5^{\circ} \mathrm{C}$ に上つても， 5 日間の泠蔵では受精率が半減する（第 2 表の支 110 参照）。また前揭の第 1 表に示し てあるように，雑種（支 $108 \times$ 日 115）の精子は，第 2 表に示してある純系に近い支 110 の精子に 比して受精率が高い。この事実は雑種強势の現象から当然考えられることである．また日支固定種の 日特の精子が，純系に近い支 110 の精子よりも受精力が高いのは，日特は日支の分離固定種であり， 支 110 は支支の 2 化固定種であるけれども，長期の育成によつて支 110 の方が純系に近いものになつ ているための両者の相異によるものと思われる.

なおここに興味あることは，第 3 表に示すように，日 $111 \times$ 支 110 の場合において成熟卵内にお ける精子の受精率が, 同品種間（支 $110 \times$ 支 110）の卵子内におけるものに比して高いことである. 一般に雑種強势の事実は遺伝学的に言えば核の優良形質の頡性的綜合組合せによる場合とされていて 一般的には卵細胞質は母体から唀導された固有なものであり, 卵細胞質それ自身は雑種強勢現象に関 与していないと考えられている. しかし第 3 表に示すように雑種 (早)×支 110 (今) の観察から卵細 胞質が雑種の形になつている場合もまた受精力の強势に一役買つていて，それが同品種の卵細胞質よ りも好影響を精子の受精作用に与えていることは興味深く感ずる.

同じようなことが次の場合にもいえる．即ち同品種間の交配の場合における精子の受精率が，異な る品種の卵細胞質内での受精率が高いことである，即ち第 3 表に示すように，支 $110 \times$ 支 110 の同 品種間の精子の受精率よりも, 異品種（日 111（守）×支 110(今)）への精子の受精率（第 3 表の産卵 1 時間経過を参照) の方が高いことも, 前記と同様に卵細胞質が精子の働く場として受精作用に好影 響を与えた結果と考えてよいと思う。

これらの事実は梅谷 $\left(1928,{ }^{\prime} 30\right)$ がさきに説いたように雑種のへテロシス現象には遺伝学者が主張 するように, 核がへテロとなる点を重視し, 受精が起る場としての卵細胞質の生理的役割を軽視する きらいがあつたことは, 以上の実験的観察から許されないと思う, 故にへテロシスの現象には少くと も細胞質も動き手として一役を買つているとの主張は本実験結果が充分裏がきしていると思う．なお これらの研究は目下続行中である. 


\section{摘 要}

1. カイコの成熟卵内の精子の受精力には， $2.5^{\circ} \mathrm{C}$ と $5^{\circ} \mathrm{C}$ の間に判然たる臨界点があることを見 出した。そしてこの $2.5^{\circ} \mathrm{C}$ への冷蔵によつて種々な受精現象を観察した。

2. $2.5^{\circ} \mathrm{C} に 5$ 日以上成熟卵を冷蔵すると精子は受精能力を消失するが， $5^{\circ} \mathrm{C}$ の冷蔵では受精が正 常に行われる.

3. $2.5^{\circ} \mathrm{C}$ の冷蔵における雑種の成熟卵内の精子は純系に近い卵細胞内の精子よりも受精率が高く また雑種の形となつている卵細胞質内の精子もまた純系の卵細胞質内の精子よりも受精率が高い.

4. 同品種間の交配よりも異品種間の交配における卵細胞質内の精子の方が受精率が高い.これら の事実は，精子が受精作用に㗢く場として卵細胞質の役割は軽視できないことを示す．雑種のへテロ シスの原理として梅谷が説いた異系統の卵細胞の好影響があるとの説を裏書きするものである.

5. 卵細胞は精子が示したような $2.5^{\circ} \mathrm{C}$ 冷蔵の受精力に対する臨界点は見出されなかつたが，一 般に卵子の $2.5^{\circ} \mathrm{C}$ への冷蔵抵抗力は強く, 精子が健全である限り受精は正常に行なわれる.

\section{文献}

梅谷与七郎 1925 ：卵巣移植及血液移注の実験特に化性変化について, 遺伝学雑誌. 3 巻 第 4 号.

1928 : 異品種間の卵巣移植不同品種の環境を異にせる 2 形質間の交配による家掻の強勢に就て 朝 蘚虫系訊験所燨告 2 巻 第 2 号.

1930 : Situdies on the Vgor of Silkworms. Bombyx moi. Genetics 15.

1952 : 形質之環境 東京 裳華房・

\section{本 会 記 事}

\section{1.榐集䡫事かわる}

編集幹事湯浅明氏:公米国の Southern Illinois University にてフルブライト交換敉授として 1 年間をすですた め,来る 8 月 28 日出発するので,同氏ののこりの任期をみたすため小野記彦氏が編集幹事に会長より体啒された。

“遺伝学雑誌”によせる原稿の送先また法閒合せ礼，てれからはつぎのようである。

東京都目黒区深沢町 東京都立大学理学部生物学敉案 小野記竞

なお，校正，校正刷，別刷などに関する問合せはつぎのほうが便利である.

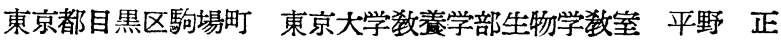

\section{2. 役員会をひらく}

1955 年 10 月 15 日（土）岡山大学にて本会役員会を開くので, 役員, 談話会または会員で同会にかけたい篦 題があるうきはななるべくまえもつて会長あてに送るてと。

\section{3. 本会会员 $下$}

本会会員に，会として，談話会として，また法会員として知らせるてと，または，はかりたいてとがあるばあ いには、できるだけ本誌の“本会記事”欄を活用したいので，会員は毎号本闌にとくに注意されたい。

\section{4. 本会第 27 回大会}

“大会にゅうす”No. 25 でみるように，本年 10 月 16-18 日，岡山大学を中心に，本大会が開かれるので， 会員住ふるつて参加されたい. な打本大会の講演要旨沙“遺伝学雑誌”Vol. 30 No.4（1955 年 9 月発行）にの せる予定である 